\title{
SISTEM PENDUKUNG KEPUTUSAN PENILAIAN DOSEN BERKUALITAS DI STMIK DUMAI MENGGUNAKAN METODE SIMPLE ADDITIVE WEIGHTING
}

\author{
Erdawati $^{1}$, Arie Linarta ${ }^{2}$, Sukri Adrianto ${ }^{3}$, Putri Yunita ${ }^{4}$ \\ ${ }^{1,2,3,4}$ Sekolah Tinggi Manajemen Informatika \& Komputer ( STMIK ) Dumai \\ Jln. Utama Karya Bukit Batrem Dumai-Riau Kode Pos 28811 \\ E-mail : erdawati@gmail.com
}

\begin{abstract}
ABSTRAK
Telah dilakukan Penelitian pada STMIK Dumai dalam menentukan dosen berkualitas dengan menggunakan metode Simple Additive Weighting (SAW). Penelitian dilatarbelakangi oleh penilaian kinerja dosen masih menggunakan sistem manual dengan menyebarkan kuisioner kepada seluruh mahasiswa. Sehingga dibuatlah sebuah sistem pendukung keputusan penilaian kinerja dosen untuk menentukan dosen berkualitas di STMIK Dumai menggunakan Metode Simple Additive Weighting (SAW). Metode SAW digunakan untuk proses perangkingan dari hasil penilaian terhadap beberapa dosen yang dilakukan oleh mahasiswa. Hasil dari proses penilaian dan perangkingan nilai yang didapatkan oleh dosen, disajikan dalam bentuk laporan penilaian kinerja dosen, laporan penilaian kinerja per dosen, dan laporan hasil perangkingan. Laporan ini dapat dijadikan sebagai bahan pertimbangan bagi pimpinan dan unsur lainnya dalam menentukan dosen berprestasi di STMIK Dumai.
\end{abstract}

Kata Kunci : SPK, Penilaian Dosen, Berkualitas, SAW

\section{PENDAHULUAN}

Kampus merupakan tempat mahasiswa melanjutkan pendidikan untuk mendapatkan gelar sarjana, untuk mendapatkan pendidikan yang layak perlu didukung oleh sarana dan prasarana bagi mahasiswa dalam melakukan aktivitas proses belajar mengajar.

Selain sarana dan prasarana yang memadai, penilaian proses belajar mengajar dilingkungan kampus juga harus menjadi prioritas utama dalam penentuan kualitas pendidikan yang diterapkan pada suatu kampus, contohnya kedisiplinan waktu, cakupan materi, modul perkuliahan, sampai teknik tenaga pengajar atau dosen dalam penyampaian materi perkuliahan juga menjadi parameter dalam menentukan keberhasilan perkuliahan yang dilaksanakan, dan tentu saja semua itu memberikan kontribusi dalam meningkatkan kualitas mahasiswa dilingkungan kampus. Di lingkungan kampus STMIK Dumai juga menerapkan sistem penilaian yang serupa, hanya saja penilaian proses belajar mengajar tersebut menggunakan kuesioner - kuesioner yang diisi secara manual, serta penyajian laporan belum menggunakan sistem komputerisasi berbasis database dan metode yang menjadi penunjang sebagai pendukung pengambilan keputusan.
Untuk mendapatkan hasil yang optimal dalam upaya peningkatan mutu pendidikan diperlukan suatu parameter untuk mengukur keberhasilan proses belajar mengajar yang telah diterapkan oleh program studi. Parameter tentu saja dapat dilakukan dengan cara pengklasifikasian kriteria yang memiliki bobot sehingga memudahkan dalam penilaian yang bertujuan sebagai tool (alat) dalam pengambilan keputusan.

Adapun tujuan penelitian ini adalah :

1. Masih belum adanya sistem pendukung keputusan yang digunakan dalam mengevaluasi kinerja dosen dalam proses belajar mengajar.

2. Masih belum maksimalnya hasil penilaian yang didapat dari kuesioner yang diisi secara manual.

3. Masih sulit dalam menentukan dosen berprestasi dalam proses belajar mengajar.

\section{a. Pengertian Sistem Pendukung Keputusan}

Sistem Pendukung Keputusan merupakan suatu sistem interaktif yang mendukung keputusan dalam proses pengambilan keputusan melalui alternatif -alternatif yang diperoleh dari hasil pengolahan data, informasi dan rancangan model. Sistem Pendukung Keputusan adalah suatu sistem informasi yang menggunakan model-model keputusan, basis data, dan pemikiran manajer 
I N F O R M A T I A

Jurnal Informatika, Manajemen dan Komputer, Vol. 8 No. 2 , Desember 2016

eISSN : 2580-3042

pISSN : 1979-0694

sendiri, proses modeling interaktif dengan komputer untuk mencapai pengambilan keputusan oleh manajer tertentu.

Dengan pengertian di atas dapat dijelaskan bahwa sistem pendukung keputusan bukan merupakan alat pengambilan keputusan, melainkan merupakan sistem yang membantu pengambil keputusan yang melengkapi mereka dengan informasi dari data yang telah diolah dan relevan dan diperluaskan untuk membuat keputusan tentang suatu masalah dengan lebih cepat dan akurat. Sehingga sistem ini tidak dimaksudkan untuk menggantikan pengambilan keputusan dalam proses pembuatan keputusan (Wahid et al, 2012).

Sistem pendukung keputusan merupakan Computer Based Information System (CBIS) yang interaktif, fleksibel, mudah disesuaikan (dapat beradaptasi) yang secara khusus dikembangkan untuk mendukung penyelesaian dari permasalahan yang tidak terstruktur untuk meningkatkan pembuatan keputusan.

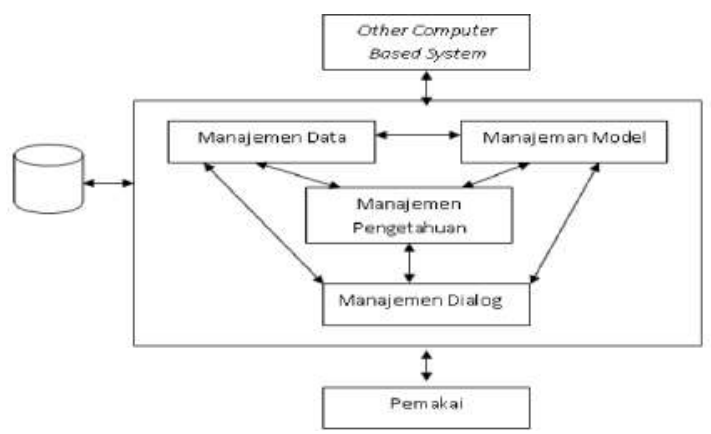

Gambar 1. Model Konseptual Sistem Pendukung Keputusan

Sumber : (Dyah et al, 2009)

Tahap-tahap yang harus dilalui dalam proses pengambilan keputusan :

1. Tahap Pemahaman

Tahap ini merupakan proses penelusuran dan pendeteksian dari lingkup problematika serta proses pengenalan masalah. Data masukan diperoleh, diproses dan diuji dalam rangka mengidentifikasikan masalah.

2. Tahap Perancangan

Tahap ini merupakan proses pengembangan dan pencarian alternatif tindakan / solusi yang dapat diambil. Solusi tersebut merupakan representasi kejadian nyata yang disederhanakan, sehingga diperlukan proses validasi dan verifikasi untuk mengetahui keakuratan model dalam meneliti masalah yang ada.

3. Tahap Pemilihan

Tahap ini dilakukan pemilihan terhadap berbagai alternatif solusi yang dimunculkan pada tahap perencanaan agar ditentukan dengan memperhatikan kriteria-kriteria berdasarkan tujuan yang akan dicapai.

4. Tahap Implementasi

Tahap ini dilakukan penerapan terhadap rancangan sistem yang telah dibuat pada tahap perancangan serta pelaksanaan alternatif tindakan yang telah dipilih pada tahap pemilihan (Syamsul, 2012).

\section{b. Komponen Sistem Pendukung Keputusan}

Sistem pendukung keputusan terdiri dari 3 (tiga) komponen utama atau subsistem yaitu :

1. Subsistem Data (Database)

Subsistem data merupakan komponen sistem pendukung keputusan penyedia data bagi sistem. Data yang dimaksud disimpan dalam suatu pangkalan data (database) yang diorganisasikan oleh suatu sistem yang disebut dengan sistem manajemen pangkalan data (Data Base Management System = DBMS). Melalui DBMS inilah data dapat diambil dan dievakuasi dengan cepat. Pangkalan data dalam sistem pendukung keputusan berasal dari dua sumber yaitu sumber internal (dari dalam perusahaan) dan sumber eksternal (dari luar perusahaan). Data eksternal ini sangat berguna bagi manajemen dalam mengambil keputusan.

2. Subsistem Model (Model Base)

Keunikan sistem pendukung keputusan adalah kemampuan dalam mengintegrasikan data dengan model-model keputusan. Model adalah suatu peniruan dari alam nyata. Kendala yang sering dihadapi dalam merancang suatu model adalah bahwa model yang disusun ternyata tidak mampu mencerminkan seluruh variable alam nyata. Sehingga keputusan yang diambil didasarkan pada model tersebut menjadi tidak akurat dan tidak sesuai dengan kebutuhan. Oleh karena itu dalam menyimpan berbagai model pada system pangkalan model harus tetap dijaga fleksibelitasnya. Hal lain yang perlu diperhatikan adalah pada setiap model yang disimpan hendaknya ditambahkan rincian keterangan dan penjelasan yang komperherensif mengenai model yang dibuat, sehingga pengguna atau perancang:

a. Mampu membuat model yang baru dengan mudah dan cepat.

b. Mampu mengakses dan mengintegrasikan sub rutin model. 
I N F O R M A T I A

Jurnal Informatika, Manajemen dan Komputer, Vol. 8 No. 2 , Desember 2016

eISSN : 2580-3042

pISSN : 1979-0694

c. Mampu menghubungkan model dengan model lain melalui pangkalan data.

d. Mampu mengelola model base dengan fungsi manajemen yang analog dengan manajemen database.

3. Subsistem Dialog (User Sistem Interface)

Keunikan lain dari sistem pendukung keputusan adalah adanya fasilitas yang mampu mengintegrasikan sistem yang terpasang dengan pengguna secara interaktif. Fasilitas atau subsistem ini dikenal sebagai subsistem dialog, inilah sistem diartikulasikan dan diimplimentasikan sehingga pengguna atau pemakai dapat berkomunikasi dengan sistem yang dirancang (Syamsul, 2012).

Menurut Pristiwanto (2014) aplikasi komponen-komponen sistem pendukung keputusan dapat terdiri dari subsistem, di antaranya :

1. Subsistem Manajemen Data

Subsistem manajemen data mencakup suatu database yang berisi data yang relevan untuk situasi dan dikelola oleh sistem manajemen basis data (Data Base Management System (DBMS)). Subsistem manajemen data dapat diinterkoneksikan dengan data warehouse perusahaan, suatu repositori untuk data perusahaan yang relevan untuk pengambil keputusan. Biasanya data disimpan atau diakses via server web database. Subsistem manajemen data dapat diinterkoneksikan dengan data warehouse perusahaan.

2. Subsistem Manajemen Model

Merupakan paket perangkat lunak yang memasukkan model keuangan, statistik, ilmu manajemen, atau model kuantitatif lainnya yang memberikan kapabilitas analitik dan manajemen perangkat lunak yang tepat.

3. Subsistem Antarmuka Pengguna

Pengguna berkomunikasi dengan dan memerintahkan sistem pendukung keputusan melalui subsistem ini. Pengguna adalah bagian yang dipertimbangkan dari sistem. Para peneliti menegaskan bahwa beberapa kontribusi unik dari sistem pendukung keputusan berasal dari interaksi yang intensif antara komputer dan pembuat keputusan.

4. Subsistem Manajemen Berbasis Pengetahuan Subsistem ini dapat mendukung semua subsistem lain atau bertindak sebagai komponen independen. Ia memberikan inteligensi untuk memperbesar pengetahuan si pengambil keputusan.

c. Metode Simple Additive Weighting (SAW)

Menurut Henry Wibowo et al (2009) dalam Diana \& Noor (2012), Fuzzy Multiple Attribute Decision Making (FMADM) adalah suatu metode yang digunakan untuk mencari alternatif optimal dari sejumlah alternatif dengan kriteria tertentu. Inti dari Fuzzy Multiple Attribute Decision Making (FMADM) adalah menentukan nilai bobot untuk setiap atribut, kemudian dilanjutkan dengan proses perankingan yang akan menyeleksi alternatif yang sudah diberikan. Pada dasarnya, ada 3 (tiga) pendekatan untuk mencari nilai bobot atribut, yaitu pendekatan subyektif, pendekatan obyektif dan pendekatan integrasi antara subyektif dan obyektif. Masing-masing pendekatan memiliki kelebihan dan kelemahan. Pada pendekatan subyektif, nilai bobot ditentukan berdasarkan subyektifitas dari para pengambil keputusan, sehingga beberapa faktor dalam proses perankingan alternatif bisa ditentukan secara bebas. Sedangkan pada pendekatan obyektif, nilai bobot dihitung secara matematis sehingga mengabaikan subyektifitas dari pengambil keputusan.

Algoritma Fuzzy Multiple Attribute Decision Making (FMADM) adalah :

1. Memberikan nilai setiap alternatif $\left(A_{i}\right)$ pada setiap kriteria $\left(C_{j}\right)$ yang sudah ditentukan, dimana nilai tersebut diperoleh berdasarkan nilai crisp; $i=1,2, \ldots m$ dan $\mathrm{j}=1,2, \ldots, \mathrm{n}$

2. Memberikan nilai bobot $(W)$ yang juga didapatkan berdasarkan nilai crisp.

3. Melakukan normalisasi matriks dengan cara menghitung nilai rating kinerja ternormalisasi $\left(r_{i}\right)$ dari alternatif $A_{i}$ pada atribut $C_{j}$ berdasarkan persamaan yang disesuaikan dengan jenis atribut (atribut keuntungan / benefit=MAKSIMUM atau atribut biaya / cost=MINIMUM). Apabila berupa atribut keuntungan maka nilai crisp $\left(x_{i}\right)$ dari setiap kolom atribut dibagi dengan nilai crisp MAX (MAX $x_{i}$ ) dari tiap kolom, sedangkan untuk atribut biaya, nilai crisp MIN (MIN $x_{i}$ ) dari tiap kolom atribut dibagi dengan nilai crisp $\left(x_{i}\right)$ setiap kolom.

4. Melakukan proses perankingan dengan cara mengalikan matriks ternormalisasi $(R)$ dengan nilai bobot $(W)$.

5. Menentukan nilai preferensi untuk setiap alternatif $\left(V_{i}\right)$ dengan cara menjumlahkan hasil kali antara matriks ternormalisasi $(R)$ dengan nilai bobot $(W)$. Nilai yang lebih besar mengindikasikan bahwa alternatif $A_{i}$ lebih terpilih.

Ada beberapa metode yang dapat digunakan untuk menyelesaikan masalah Fuzzy 
I N F O R M A T I A

Jurnal Informatika, Manajemen dan Komputer, Vol. 8 No. 2 , Desember 2016

eISSN : 2580-3042

pISSN : 1979-0694

Multiple Attribute Decision Making (FMADM), antara lain :

1. Simple Additive Weighting (SAW)

2. Weighted Product (WP)

3. ELECTRE

4. Technique for Order Prefrence by Similarity to Ideal Solution (TOPSIS)

5. Analytic Hierarchy Process (AHP)

Dalam pembahasan ini, diantara 5 (lima) metode dalam menyelesaikan masalah FMADM yang digunakan ialah Simple Additive Weighting (SAW).

Menurut Pratomo Setiaji (2012), Metode Simple Additive Weighting (SAW) sering juga dikenal istilah metode penjumlahan terbobot. Konsep dasar metode SAW adalah mencari penjumlahan terbobot dari rating kinerja pada setiap alternatif pada semua atribut. Metode SAW membutuhkan proses normalisasi matriks keputusan (X) ke suatu skala yang dapat diperbandingkan dengan semua rating alternatif yang ada.

\section{d. Kelebihan dan Kekurangan Metode SAW}

Metode SAW ini memiliki beberapa kelebihan dibandingkan dengan metode lainnya, yakni:

1. Menentukan nilai bobot untuk setiap atribut, kemudian dilanjutkan dengan proses perangkingan yang akan menyeleksi alternatif terbaik dari sejumlah alternatif.

2. Penilaian akan lebih tepat karena didasarkan pada nilai kriteria dari bobot preferensi yang sudah ditentukan.

3. Adanya perhitungan normalisasi matriks sesuai dengan nilai atribut (antara nilai benefit dan cost)

Sedangkan kekurangan dalam penggunaan metode Simple Additive Weighting (SAW) ini ialah:

1. Digunakan pada pembobotan lokal

2. Perhitungan dilakukan dengan menggunakan bilangan crisp maupun fuzzy. (Meriano, 2015)

e. Langkah Penyelesaian Metode Simple Additive Weighting (SAW)

Langkah - langkah Penyelesaian Metode

Simple Additive Weighting (SAW) sebagai berikut:

1. Menentukan kriteria-kriteria yang akan dijadikan acuan dalam pengambilan keputusan, yaitu $\mathrm{Ci}$.

2. Menentukan rating kecocokan setiap alternatif pada setiap kriteria.

3. Membuat matriks keputusan berdasarkan criteria (Ci), kemudian melakukan

normalisasi matriks berdasarkan persamaan yang disesuaikan dengan jenis atribut (atribut keuntungan ataupun atribut biaya) sehingga diperoleh matriks ternormalisasi $\mathrm{R}$.

4. Hasil akhir diperoleh dari proses perankingan yaitu penjumlahan dari perkalian matriks ternormalisasi $\mathrm{R}$ dengan vektor bobot sehingga diperoleh nilai terbesar yang dipilih sebagai alternative terbaik (Ai) sebagai solusi.

Rumus untuk melakukan normalisasi tersebut adalah:

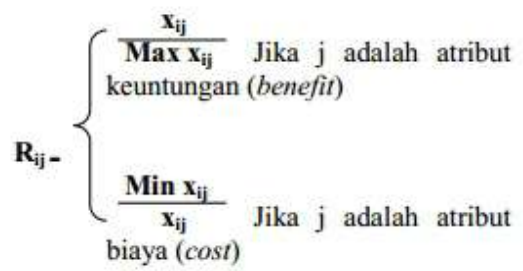

Dimana:

$\mathrm{r}_{\mathrm{ij}}=$ rating kinerja ternormalisasi

$\mathrm{Max}_{\mathrm{ij}}=$ nilai maksimum dari setiap baris dan kolom

$\operatorname{Min}_{\mathrm{ij}}=$ nilai minimum dari setiap baris dan kolom

$\mathrm{X}_{\mathrm{ii}}=$ baris dan kolom dari matriks

Dengan $\mathrm{r}_{\mathrm{ij}}$ adalah rating kinerja ternormalisasi dari alternatif $A_{i}$ pada atribut $C_{j} ; i=1,2,, m$ dan $j=$ $1,2,,, n$.

Nilai preferensi untuk setiap alternatif $\left(\mathrm{V}_{\mathrm{i}}\right)$ diberikan sebagai:

$$
\nu_{i}=\sum_{j=1}^{n} w_{j} r_{i j}
$$

Dimana :

$\mathrm{V}_{\mathrm{i}}=$ Nilai akhir dari alternatif

$\mathrm{W}_{\mathrm{i}}=$ Bobot yang telah ditentukan

$\mathrm{r}_{\mathrm{ii}}=$ Normalisasi matriks

Nilai $V_{i}$ yang lebih besar mengindikasikan bahwa alternatif $A_{i}$ lebih terpilih.

\section{METODOLOGI PENELITIAN}

Adapun jenis-jenis metode penelitian yang digunakan untuk mendapatkan data-data tersebut adalah sebagai berikut :

1. Tempat dan Waktu Penelitian

Penelitan ini dilakukan dilingkungan Kampus STMIK Dumai.

2. Jenis Penelitian

Jenis penelitian yang dilakukan dalam karya ilmiah ini ialah melakukan survei kepada sebagian mahasiswa STMIK dumai dengan menyebarkan kuisioner untuk menghasilkan data yang nantinya akan menjadi bahan dalam 
I N F O R M A T I K

Jurnal Informatika, Manajemen dan Komputer, Vol. 8 No. 2 , Desember 2016

eISSN : 2580-3042

pISSN : 1979-0694

melakukan penilaian kinerja dosen pada proses belajar mengajar.

3. Teknik Analisa Data

Teknik yang digunakan dalam menganalisa data dengan melakukan beberapa tahapan yaitu :

a. Interview (Wawancara), yaitu: Dalam hal ini penulis melakukan wawancara dengan mahasiswa, dan dosen serta prodi pada setiap perkuliahan yang dijadikan sampel dalam upaya mendapatkan data yang diperlukan.

b. Observasi, yaitu : Melakukan observasi secara langsung dan mencatat masalah yang bersangkutan dengan pemilihan judul yang penulis ajukan.

c. Laboratory Research (Penelitian Laboratorium), yaitu : Penelitian yang dilakukan dalam laboratorium komputer yang berguna untuk mengadakan penelitian langsung dengan komputer untuk mengimplementasikan sistem pendukung keputusan penilaian proses belajar di STMIK Dumai

d. Library Research (Penelitian Perpustakaan), yaitu : Penelitian yang dilakukan dengan menggunakan refrensi buku - buku dan jurnal sebagai landasan teori dalam pembuatan penelitian ini.

\section{HASIL DAN PEMBAHASAN}

a. Analisa Perhitungan Manual Metode $S A W$ Berdasarkan dari penelitian yang dilakukan penulis, berikut penerapan dari SPK yang digunakan dalam penyeleksian dosen terbaik di STMIK Dumai menggunakan Metode Simple Additive Weighting ( $S A W)$.

A. Alternatif Dosen yang akan dinilai

Pada deskripsi penilaian alternatif dosen, terdapat 5 orang dosen pada STMIK Dumai yaitu :

1. Dosen A

2. Dosen B

3. Dosen $\mathrm{C}$

4. Dosen D

5. Dosen E

B. Kriteria Penilaian

Adapun kriteria sebagai perbandingan adalah seperti dibawah ini :

1. Ketersediaan buku ajar fasilitas ruangan $(\mathrm{C} 1)$

2. Ketepatan waktu dosen memulai dan menyudahi perkuliahan $(\mathrm{C} 2)$

3. Penguasaan materi dosen (C3)

4. Strategi dan metode pengajaran $(\mathrm{C} 4)$

5. Kejelasan penyampaian materi (C5)

6. Daya serap mahasiswa pada materi yang disampaikan (C6)

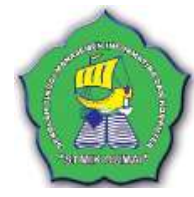

7. Kesesuaian pembelajaran dengan silabus (C7)

8. Upaya dosen dalam mengaktifkan suasana kelas (C8)

Dari masing-masing kriteria tersebut akan ditentukan bobot-bobotnya. Pada bobot terdiri dari lima bilangan, yaitu rendah, cukup, sedang, baik dan baik sekali seperti terlihat pada tabel 9 .

Tabel 1. Tabel Bobot

\begin{tabular}{|l|c|}
\hline \multicolumn{1}{|c|}{ Kriteria } & Nilai \\
\hline Rendah & 1 \\
\hline Cukup & 2 \\
\hline Sedang & 3 \\
\hline Baik & 4 \\
\hline Baik Sekali & 5 \\
\hline
\end{tabular}

Berdasarkan kriteria dan rating kecocokan setiap alternatif pada setiap kriteria yang telah ditentukan, selanjutnya penjabaran bobot setiap kriteria.

Tabel 2. Ketersediaan buku ajar fasilitas ruangan

\begin{tabular}{|l|l|c|}
\hline \multicolumn{1}{|c|}{ Kriteria } & $\begin{array}{c}\text { Buku dan Fasilitas Ruangan } \\
(\mathrm{C} 1)\end{array}$ & Nilai \\
\hline Rendah & Tidak Memadai & 1 \\
\hline Cukup & Kurang Memadai & 2 \\
\hline Sedang & Memadai & 3 \\
\hline Baik & Standar & 4 \\
\hline Baik Sekali & Lengkap & 5 \\
\hline
\end{tabular}

Tabel 3. Ketepatan waktu dosen memulai dan menyudahi perkuliahan

\begin{tabular}{|c|c|c|}
\hline Kriteria & Kehadiran Dosen (C2) & Nilai \\
\hline Rendah & $\begin{array}{l}\text { Sering Tidak Masuk dan } \\
\text { Terlambat }\end{array}$ & 1 \\
\hline Cukup & Sering Tidak masuk & 2 \\
\hline Sedang & Sering Terlambat & 3 \\
\hline Baik & Selalu Hadir & 4 \\
\hline Baik Sekali & $\begin{array}{l}\text { Selalu Hadir dan Tepat } \\
\text { Waktu }\end{array}$ & 5 \\
\hline
\end{tabular}

Tabel 4. Penguasaan materi dosen

\begin{tabular}{|l|l|c|}
\hline \multicolumn{1}{|c|}{ Kriteria } & $\begin{array}{c}\text { Penguasaan materi dosen } \\
\text { (C3) }\end{array}$ & Nilai \\
\hline Rendah & Tidak Menguasai & 1 \\
\hline Cukup & Kurang Menguasai & 2 \\
\hline Sedang & Cukup Menguasai & 3 \\
\hline Baik & Menguasai & 4 \\
\hline Baik Sekali & Sangat menguasai & 5 \\
\hline
\end{tabular}


I N F ORM I T I K

Jurnal Informatika, Manajemen dan Komputer, Vol. 8 No. 2 , Desember 2016

eISSN : 2580-3042

pISSN : 1979-0694

Tabel 5. Strategi dan metode pengajaran

\begin{tabular}{|l|l|c|}
\hline \multicolumn{1}{|c|}{ Kriteria } & \multicolumn{1}{|c|}{$\begin{array}{c}\text { Strategi dan metode } \\
\text { mengajar dosen (C4) }\end{array}$} & Nilai \\
\hline Rendah & Pasif & 1 \\
\hline Cukup & Teoritis dan pasif & 2 \\
\hline Sedang & Teoritis dan aktif & 3 \\
\hline Baik & Terapan, teoritis dan pasif & 4 \\
\hline Baik Sekali & $\begin{array}{l}\text { Terapan, teoritis, praktek } \\
\text { dan aktif }\end{array}$ & 5 \\
\hline
\end{tabular}

Tabel 6. Kejelasan penyampaian materi

\begin{tabular}{|l|l|c|}
\hline Kriteria & $\begin{array}{c}\text { Kejelasan penyamapaian } \\
\text { materi (5) }\end{array}$ & Nilai \\
\hline Rendah & Tidak Jelas & 1 \\
\hline Cukup & Kurang jelas & 2 \\
\hline Sedang & Cukup Jelas & 3 \\
\hline Baik & Jelas & 4 \\
\hline Baik Sekali & Sangat jelas & 5 \\
\hline
\end{tabular}

Tabel 7. Daya serap mahasiswa pada materi yang disampaikan

\begin{tabular}{|l|l|c|}
\hline Kriteria & $\begin{array}{l}\text { Daya serap mahasiswa pada } \\
\text { materi yang disampaikan } \\
(6)\end{array}$ & Nilai \\
\hline Rendah & Tidak Baik & 1 \\
\hline Cukup & Kurang Baik & 2 \\
\hline Sedang & Cukup Baik & 3 \\
\hline Baik & Baik & 4 \\
\hline Baik Sekali & Sangat Baik & 5 \\
\hline
\end{tabular}

Tabel 8. Proses Kesesuaian pembelajaran dengan silabus

\begin{tabular}{|l|l|c|}
\hline \multicolumn{1}{|c|}{ Kriteria } & $\begin{array}{l}\text { Proses pembelajaran sudah } \\
\text { sesuai dengan silabus dan } \\
\text { SAP (7) }\end{array}$ & Nilai \\
\hline Rendah & Tidak sesuai & 1 \\
\hline Cukup & Kurang Sesuai & 2 \\
\hline Sedang & Agak Melenceng & 3 \\
\hline Baik & Sesuai & 4 \\
\hline Baik Sekali & Sangat Sesuai dan lengkap & 5 \\
\hline
\end{tabular}

Tabel 9. Upaya dosen dalam mengaktifkan suasana kelas

\begin{tabular}{|l|l|c|}
\hline \multicolumn{1}{|c|}{ Kriteria } & $\begin{array}{c}\text { Kejelasan penyamapaian } \\
\text { materi (8) }\end{array}$ & Nilai \\
\hline Rendah & Tidak Baik & 1 \\
\hline Cukup & Kurang Baik & 2 \\
\hline Sedang & Cukup Baik & 3 \\
\hline Baik & Baik & 4 \\
\hline
\end{tabular}

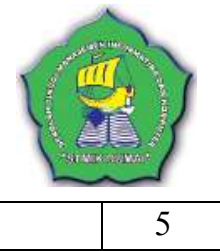

Berikut ini adalah contoh tabel kasus dari perhitungan SAW pada 5 orang dosen yang dinilai 1 (satu) orang mahasiswa

Tabel 10 Penilaian Dosen Oleh Mahasiswa

\begin{tabular}{|c|c|c|c|c|c|c|c|c|}
\hline $\mathrm{V}$ & $\mathrm{Cl}$ & $\mathrm{Cl}$ & G & C & $\sigma$ & $c 6$ & C & $\alpha$ \\
\hline DexanA & Iengasp & BeringTde & Ousup & Pasil' & Jetas & Burzang teass & Kungugsesia & 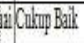 \\
\hline$D \cos B$ & Pancis & 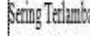 & Galluang & Teacobis \& & Busang Ftass & Jids & ITidatsessoud & Krong Bali. \\
\hline Dxwanc & Memital & sealn Fadir & Mergasii & Tleanisis & Singgtidels & Singatilits & Servili & Bul \\
\hline Dsean D & Iengixpp & Selalu Fadir & Colsup & Pasiti & Detas & Jelds & Kinnghsoria & Bill \\
\hline $\operatorname{sen} E$ & Sandiar & Primgle & 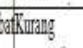 & leactibs \& & Rurang felas & Burang Jetas & Tidatsesoud & Culupp Ball: \\
\hline
\end{tabular}

Berdasarkan data dosen diatas dapat dibentuk matriks keputusan $\mathrm{x}$, sebagai berikut :

Tabel 11 Rating kecocokan dari setiap alternative penilaian pada setiap criteria penilaian Mahasiswa

\begin{tabular}{|c|c|c|c|c|c|c|c|c|}
\hline \multirow{2}{*}{ Alematff } & \multicolumn{8}{|c|}{ Kintema } \\
\hline & $\mathrm{Cl}$ & C & C & $C A$ & $C 5$ & $c k$ & $C 7$ & $\mathrm{Cl}$ \\
\hline Dosen A & 5 & 2 & 3 & 1 & 4 & 2 & 2 & 3 \\
\hline Dosen B & 4 & 3 & 2 & 2 & 2 & 4 & 1 & $?$ \\
\hline Dosen C & 3 & 4 & 4 & 3 & $j$ & 5 & 4 & 4 \\
\hline Dosen D & 5 & 4 & 3 & 1 & 4 & 4 & $?$ & 4 \\
\hline Dosen $E$ & 4 & 3 & 2 & 2 & 2 & 2 & 1 & 3 \\
\hline Dosen E & $j$ & 3 & 2 & 1 & 4 & 4 & $?$ & 3 \\
\hline
\end{tabular}

Pengambilan keputusan memberikan bobot, berdasarkan tingkat kepentingan masing-masing kriteria yang dibutuhkan sebagai berikut :

Vektor bobot : $\mathrm{W}=[5,5,5,3,4,3,4,3]$

Membuat matriks keputusan $\mathrm{x}$, dibuat dari tabel kecocokan sebagai berikut :

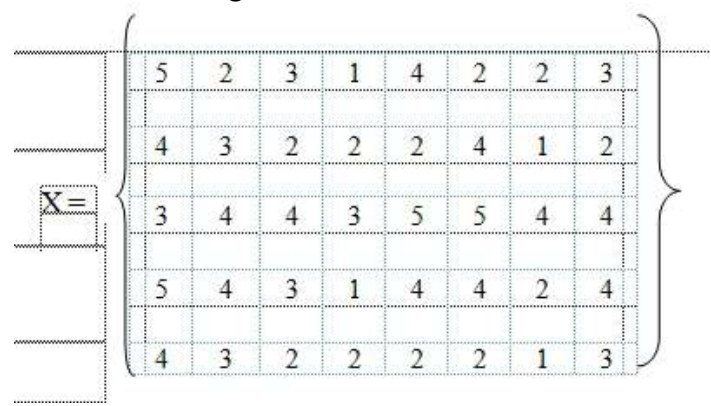

Pertama dilakukan normalisasi matriks $\mathrm{X}$ untuk menghitung nilai masing-masing kriteria berdasarkan kriteria diasumsi sebagai berikut:

$$
\begin{aligned}
& r 11=\frac{5}{\mathrm{M}(5 ; 4 ; 3 ; 5 ; 4)}=\frac{5}{5}=1 \\
& r 12=\frac{2}{\mathrm{M}(2 ; 3 ; 4 ; 4 ; 4)}=\frac{2}{4}=0,5
\end{aligned}
$$


I N F ORM A I K A

Jurnal Informatika, Manajemen dan Komputer, Vol. 8 No. 2 , Desember 2016

eISSN : 2580-3042

pISSN : 1979-0694

$$
\begin{aligned}
& r 13=\frac{3}{\mathrm{M} \quad(3 ; 2 ; 4 ; 3 ; 2)}=\frac{3}{4}=0,75 \\
& r 14=\frac{1}{\mathrm{M} \quad(1 ; 2 ; 3 ; 1 ; 2)}=\frac{1}{3}=0,33 \\
& r 15=\frac{4}{\mathrm{M} \quad(4 ; 2 ; 5 ; 4 ; 2)}=\frac{4}{5}=0,8 \\
& r 16=\frac{2}{\mathrm{M} \quad(2 ; 4 ; 5 ; 4 ; 2)}=\frac{2}{5}=0,4 \\
& r 17=\frac{2}{\mathrm{M} \quad(2 ; 1 ; 4 ; 2 ; 1)}=\frac{2}{4}=0,5 \\
& r 18=\frac{3}{\mathrm{M} \quad(3 ; 2 ; 4 ; 4 ; 3)}=\frac{3}{4}=0,75 \\
& r 21=\frac{4}{\mathrm{M} \quad(5 ; 4 ; 3 ; 5 ; 4)} \quad=\frac{4}{5}=0,8 \\
& r 22=\frac{3}{\mathrm{M} \quad(2 ; 3 ; 4 ; 4 ; 4)}=\frac{3}{4}=0,75 \\
& r 23=\frac{2}{\mathrm{M} \quad(3 ; 2 ; 4 ; 3 ; 2)}=\frac{2}{4}=0,5 \\
& r 24=\frac{2}{\mathrm{M} \quad(1 ; 2 ; 3 ; 1 ; 2)}=\frac{2}{3}=0,66 \\
& r 25=\frac{2}{\mathrm{M} \quad(4 ; 2 ; 5 ; 4 ; 2)}=\frac{2}{5}=0,4 \\
& r 26=\frac{4}{\mathrm{M} \quad(2 ; 4 ; 5 ; 4 ; 2)}=\frac{4}{5}=0,8 \\
& r 27=\frac{1}{\mathrm{M} \quad(2 ; 1 ; 4 ; 2 ; 1)}=\frac{1}{4}=0,25 \\
& r 28=\frac{2}{\mathrm{M} \quad(3 ; 2 ; 4 ; 4 ; 3)}=\frac{2}{4}=0,5 \\
& r 31=\frac{3}{\mathrm{M}(5 ; 4 ; 3 ; 5 ; 4)} \quad=\frac{3}{5}=0,6 \\
& r 32=\frac{4}{\mathrm{M} \quad(2 ; 3 ; 4 ; 4 ; 4)}=\frac{4}{4}=1 \\
& r 33=\frac{4}{\mathrm{M} \quad(3 ; 2 ; 4 ; 3 ; 2)}=\frac{4}{4}=1 \\
& r 34=\frac{3}{\mathrm{M} \quad(1 ; 2 ; 3 ; 1 ; 2)}=\frac{3}{3}=1 \\
& r 35=\frac{5}{\mathrm{M} \quad(4 ; 2 ; 5 ; 4 ; 2)}=\frac{5}{5}=1 \\
& r 36=\frac{5}{\mathrm{M} \quad(2 ; 4 ; 5 ; 4 ; 2)}=\frac{5}{5}=1 \\
& r 37=\frac{4}{\mathrm{M} \quad(2 ; 1 ; 4 ; 2 ; 1)}=\frac{4}{4}=1 \\
& r 38=\frac{4}{\mathrm{M} \quad(3 ; 2 ; 4 ; 4 ; 3)}=\frac{4}{4}=1 \\
& r 41=\frac{5}{\mathrm{M} \quad(5 ; 4 ; 3 ; 5 ; 4)}=\frac{5}{5}=1 \\
& r 42=\frac{4}{\mathrm{M} \quad(2 ; 3 ; 4 ; 4 ; 4)}=\frac{4}{4}=1 \\
& r 43=\frac{3}{\mathrm{M} \quad(3 ; 2 ; 4 ; 3 ; 2)}=\frac{3}{4}=0,75 \\
& r 44=\frac{1}{\mathrm{M} \quad(1 ; 2 ; 3 ; 1 ; 2)}=\frac{1}{3}=0,33 \\
& r 45=\frac{4}{\mathrm{M} \quad(4 ; 2 ; 5 ; 4 ; 2)}=\frac{4}{5}=0,8 \\
& r 46=\frac{4}{\mathrm{M} \quad(2 ; 4 ; 5 ; 4 ; 2)}=\frac{4}{5}=0,8 \\
& r 47=\frac{2}{\mathrm{M} \quad(2 ; 1 ; 4 ; 2 ; 1)}=\frac{2}{4}=0,5 \\
& r 48=\frac{4}{\mathrm{M} \quad(3 ; 2 ; 4 ; 4 ; 3)}=\frac{4}{4}=1 \\
& r 51=\frac{4}{\mathrm{M} \quad(5 ; 4 ; 3 ; 5 ; 4)}=\frac{4}{5}=0,8 \\
& r 52=\frac{3}{\mathrm{M} \quad(2 ; 3 ; 4 ; 4 ; 4)}=\frac{3}{4}=0,75 \\
& r 53=\frac{2}{\mathrm{M} \quad(3 ; 2 ; 4 ; 3 ; 2)}=\frac{2}{4}=0,5 \\
& r 54=\frac{2}{\mathrm{M} \quad(1 ; 2 ; 3 ; 1 ; 2)}=\frac{2}{3}=0,66 \\
& r 55=\frac{2}{\mathrm{M} \quad(4 ; 2 ; 5 ; 4 ; 2)}=\frac{2}{5}=0,4 \\
& r 56=\frac{2}{\mathrm{M} \quad(2 ; 4 ; 5 ; 4 ; 2)}=\frac{2}{5}=0,4
\end{aligned}
$$

$$
\begin{aligned}
& r 57=\frac{1}{\mathrm{M}(2 ; 1 ; 4 ; 2 ; 1)}=\frac{1}{4}=0,25 \\
& r 58=\frac{3}{\mathrm{M}(3 ; 2 ; 4 ; 4 ; 3)}=\frac{3}{4}=0,75
\end{aligned}
$$

Kedua, membuat normalisasi matriks $\mathrm{R}$ yang diperoleh dari hasil normalisasi matriks $\mathrm{X}$ sebagai berikut :

$\mathrm{R}=\left\{\begin{array}{cc|cccc|ccc}1 & 0,5 & 0,75 & 0,33 & 0,8 & 0,4 & 0,5 & 0,75 \\ \hline & & & & & & & \\ 0,8 & 0,75 & 0,5 & 0,66 & 0,4 & 0,8 & 0,25 & 0,5 \\ \hline 0,6 & 1 & 1 & 1 & 1 & 1 & 1 & 1 \\ \hline & & & & & & & \\ \hline 1 & 1 & 0,75 & 0,33 & 0,8 & 0,8 & 0,5 & 1 \\ \hdashline & & & & & & & \\ 0,8 & 0,75 & 0,5 & 0,66 & 0,4 & 0,4 & 0,25 & 0,75\end{array}\right\}$

Selanjutnya akan dibuat perkalian matriks $\mathrm{W} * \mathrm{R}$ dan penjumlahan hasil perkalian untuk memperoleh alternatif terbaik dengan melakukan perangkingan nilai terbesar sebagai berikut:

$$
\begin{aligned}
& \mathrm{V} 1=(5)(1)+(5)(0,5)+(5)(0,75)+(3)(0,33)+ \\
& (4)(0,8)+(3)(0,4)+(4)(0,5)+(3)(0,75) \\
& =20,89 \\
& \mathrm{~V} 2=(5)(0,8)+(5)(0,75)+(5)(0,5)+(3)(0,66)+ \\
& (4)(0,4)+(3)(0,8)+(4)(0,25)+(3)(0,5) \\
& =18,73 \\
& \mathrm{~V} 3=(5)(0,6)+(5)(1)+(5)(1)+(3)(1)+(4)+(1) \\
& +(3)(1)+(4)(1)+(3)(1) \\
& =30 \\
& \mathrm{~V} 4=(5)(1)+(5)(1)+(5)(0,75)+(3)(0,33)+ \\
& (4)(0,8)+(3)(0,8)+(4)(0,5)+(3)(1) \\
& =25,34 \\
& \mathrm{~V} 5=(5)(0,8)+(5)(0,75)+(5)(0,5)+(3)(0,66)+ \\
& (4)(0,4)+(3)(0,4)+(4)(0,25)+(3)(0,75) \\
& =18,28
\end{aligned}
$$

Dari perhitungan bobot tersebut dosen ketiga yaitu Dosen $\mathbf{C}$ yang menjadi dosen terbaik dengan perolehan nilai tertinggi yaitu : $\underline{\mathbf{3 0}}$

\section{b. Implementasi Sistem}

Pada form data kriteria, admin dan pimpinan dapat menambahkan, merubah dan menghapus kriteria yang nantinya digunakan untuk proses penilaian dalam menentukan dosen berprestasi di STMIK Dumai.

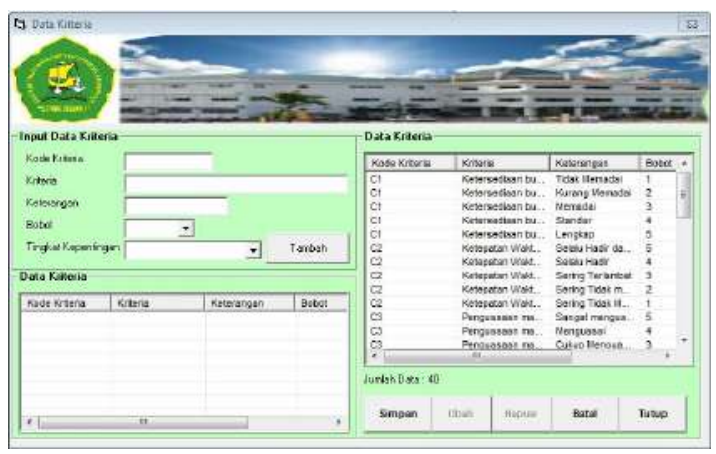

Gambar 2. Form Data Kriteria 
I N F O R M A T I K A

Jurnal Informatika, Manajemen dan Komputer, Vol. 8 No. 2 , Desember 2016

elSSN : 2580-3042

pISSN : 1979-0694

Pada form data bobot kepentingan, admin dan pimpinan dapat merubah tingkat kepentingan suatu bobot dari kriteria yang telah di-input-kan sebelumnya sesuai dengan keperluan, yang nantinya akan digunakan dalam proses perhitungan nilai untuk menghasilkan nilai dari tiap dosen menggunakan metode SAW.

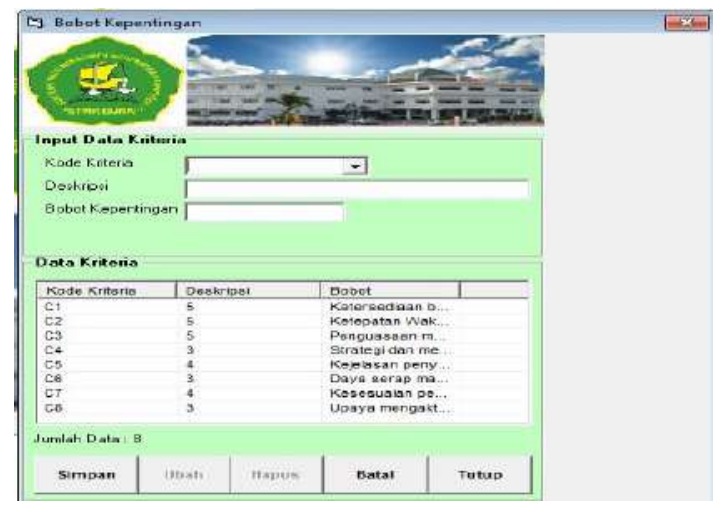

Gambar 3. Form Data BobotKepentingan

Pada form data penilaian yang diperuntukkan bagi mahasiswa, sesuai dengan data mahasiswa yang telah diinputkan oleh admin sebelumnya, mahasiswa dapat memilih NIM sesuai yang dimilikinya untuk melakukan proses penilaian. Setelah itu, mahasiswa diharuskan memilih nama dosen dengan mengklik nama dosen dan menginputkan penilaiannya. Kemudian meng-klik tombol tambah dan memilih kembali dosen selanjutnya. Setelah kelima dosen diberikan penilaian, maka mahasiswa dapat menyimpan dan keluar dari form data penilaian.

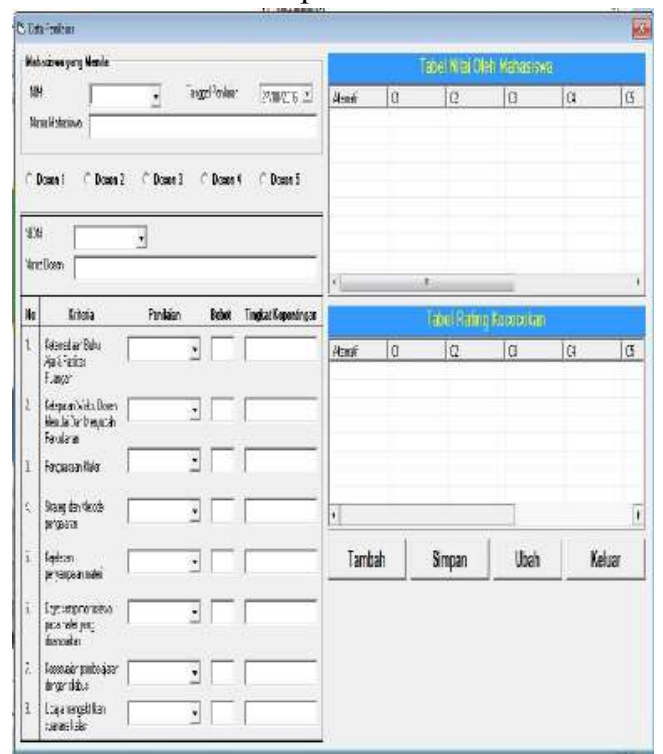

Gambar 4. Form Data Penilaian
Pada form data perangkingan, admin maupun pimpinan dapat memilih mahasiswa yang telah melakukan penilaian, dengan mengklik combo pada NIM, setelah muncul notifikasi data ditemukan, dan akan muncul seluruh hasil penilaian yang telah diberikan pada tiap dosen, admin ataupun pimpinan dapat mengklik tombol "proses perhitungan SAW". Dengan begitu akan muncul hasil dari perhitungan SAW dan nilai dari masing-masing dosen. Setelah perhitungan selesai, klik tombol simpan hasil perhitungan untuk menyimpan data perhitungan ke dalam database.

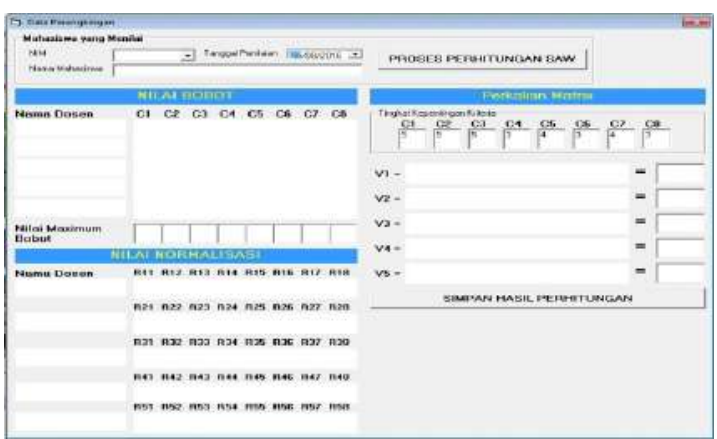

Gambar 5. Form Data Perangkingan

Form laporan, berisikan tiga macam laporan, yakni laporan penilaian dosen, laporan penilaian per dosen dan laporan perangkingan.

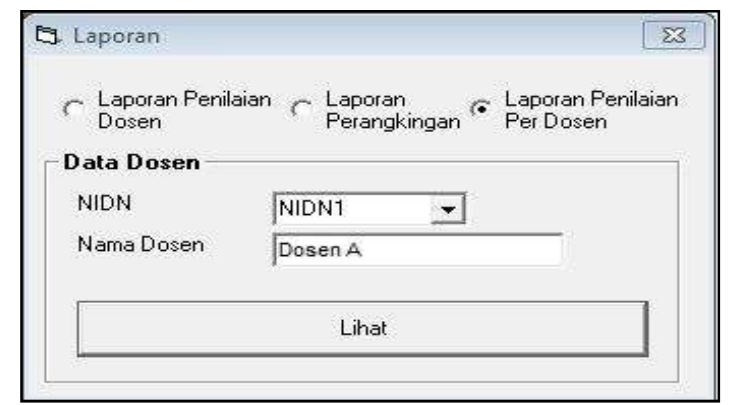

Gambar 6. Form Laporan

Saat Admin dan Pimpinan memilih laporan penilaian dosen, maka akan muncul seluruh hasil penilaian yang telah diisikan oleh mahasiswa.

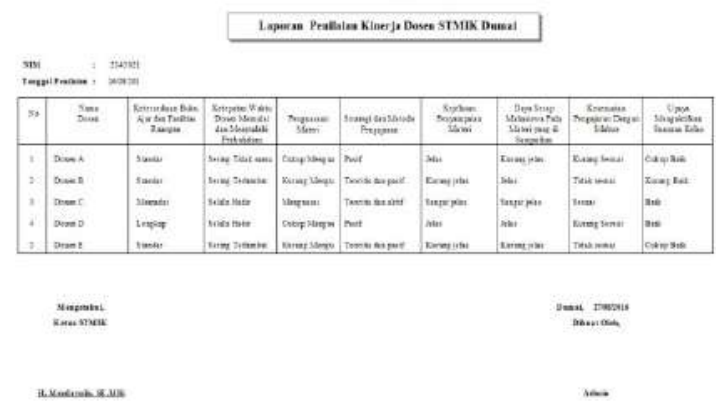

Gambar 7. Laporan Penilaian Kinerja Dosen 
I N F ORM A I K A

Jurnal Informatika, Manajemen dan Komputer, Vol. 8 No. 2 , Desember 2016

eISSN : 2580-3042

pISSN : 1979-0694

\section{KESIMPULAN}

Dari uraian pada bab-bab yang sudah dibahas sebelumnya dapat ditarik kesimpulan

1. Dengan adanya sistem pendukung keputusan dalam penentuan dosen berkualitas di STMIK Dumai, dapat menjadi bahan pertimbangan bagi Pimpinan dan Jajaran kampus dalam menentukan dosen berprestasi.

2. Proses penilaian kinerja dosen dalam menentukan dosen berprestasi yang sebelumnya menggunakan sistem manual dengan menyebarkan kuisioner, dengan adanya sistem penilaian ini dapat mempermudah dalam proses penilaian dan perhitungan nilai khususnya menggunakan metode Simple Additive Weighting (SAW).

3. Proses penilaian kinerja dosen dalam menentukan dosen berprestasi dengan menggunakan metode Simple Additive Weighting (SAW), menghasilkan data yang lebih valid dan objektif bila dibandingkan dengan perhitungan yang dilakukan secara manual.

\section{REFERENSI}

Adi Nugroho.(2011). Perancangan Dan Implementasi Sistem Basis Data. CV. Andi Offset, Yogyakarta.

Aji Dewantoro. (2015). Sistem Pendukung Keputusan Menentukan Guru Teladan Di SMPN 24 Semarang Dengan Menggunakan Metode Simple Additive Weighting. PSI UDINUS

Bunafit Nugroho.(2014). Panduan Membuat Aplikasi Inventory Barang Dengan Visual Basic 6. PT. Gramedia, Jakarta.

Bunafit Nugroho.(2005). Database Relasional dengan MYSQL. CV. Andi Offset, Yogyakarta.

Diana \& Noor, (2012), Sistem Pendukung Keputusan Untuk Pemberian Bantuan Usaha Mikro dengan Metode Simple Additive Weighting, Majalah Ilmiah Informatika. Vol. 3 No. 2

Fathansyah. (2012). Basis Data. Informatika. Bandung.

Jogiyanto, H.M. (2009). Sistem Teknologi Informasi. CV. Andi Offset, Yogyakarta.

Irnawan dan Yesni Malau. (2011). Apapun Permintaan Crystal Report Jawabnya. PT. Elex Media Komputindo. Jakarta.

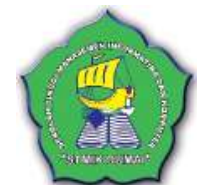

Madcoms. (2009). Seri Panduan Pemograman Database Visual Basic 6.0 Dengan Crystal Reports. CV. Andi Offset.Yogyakarta.

Meriano Setya D.U. (2015). Penerapan Metode Simple Additive Weight Pada Sistem Pendukung

KeputusanUntukPemberianBeasiswaPada SMA Negeri 1 Cepu Jawa Tengah. PSI UDINUS

Pratomo Setiaji, (2012). Sistem Pendukung Keputusan Dengan Metode Simple Additive Weighting. Jurnal Simetris, Vol. 1 No. 1

Rahmat Putra. (2006). Inovatif Source Code Visual Basic. Dian Rakyat. Jakarta.

Rahmat Putra dan Malik Akbar. (2005). 140 Trik Inovatif Visual Bsic. PT. Elex Media Komputindo. Jakarta.

Uus Rusmawan, (2005). Merancang Koneksi Database dalam Visual Basic 6.0, PT. Elex Media Komputindo. Jakarta.

Windra Swastika, (2006). Resep Visual Basic. Dian Rakyat. Jakarta.

Said Mirza Pahlevi.(2013). Tujuh Langkah Praktis Pembangunan Basis Data. PT. Elex Media Komputindo. Jakarta.

Tata Sutabri, (2012). Konsep Sistem Informasi. CV.Andi Offset. Yogyakarta.

Yudi Priyadi, (2014). Kolaborasi SQL \& ERD Dalam Implementasi Database. CV.Andi Offset. Yogyakarta. 